\begin{tabular}{|c|c|}
\hline Title & $\begin{array}{l}\text { The 3-hydroxy group of lanosterol is essential for orienting the substrate in the substrate site of } \\
\text { cytochrome P-450 }{ }_{14} \mathrm{DM} \text { (lanosterol 14a-demethylase) }\end{array}$ \\
\hline \multicolumn{2}{|l|}{ Sub Title } \\
\hline Author & \begin{tabular}{|l|} 
青山, 由利(Aoyama, Yuri) \\
吉田，雄三(Yoshida, Yuzo) \\
園田，よし子(Sonoda, Yoshiko) \\
佐藤，良博(Sato, Yoshihiro)
\end{tabular} \\
\hline Publisher & 共立薬科大学 \\
\hline Publication year & 1990 \\
\hline Jtitle & $\begin{array}{l}\text { 共立薬科大学研究年報 (The annual report of the Kyoritsu College of } \\
\text { Pharmacy). No.35 (1990.) , p.54- } 54\end{array}$ \\
\hline \multicolumn{2}{|l|}{ JaLC DOI } \\
\hline \multicolumn{2}{|l|}{ Abstract } \\
\hline Notes & 抄録 \\
\hline Genre & Technical Report \\
\hline URL & $\begin{array}{l}\text { https://koara.lib.keio.ac.jp/xoonips/modules/xoonips/detail.php?koara_id=AN00062898-0000003 } \\
\text { 5-0054 }\end{array}$ \\
\hline
\end{tabular}

慶應義塾大学学術情報リポジトリ(KOARA)に掲載されているコンテンツの著作権は、それぞれの著作者、学会または出版社/発行者に帰属し、その権利は著作権法によって 保護されています。引用にあたっては、著作権法を遵守してご利用ください。

The copyrights of content available on the KeiO Associated Repository of Academic resources (KOARA) belong to the respective authors, academic societies, or publishers/issuers, and these rights are protected by the Japanese Copyright Act. When quoting the content, please follow the Japanese copyright act. 


\title{
The 3-hydroxy group of lanosterol is essential for orienting the substrate in the substrate site of cytochrome P-450 (Lanosterol 14 $\alpha$-demethylase)
}

\author{
Yuri Aoyama*, Yuzo Yoshida,* Yoshiko Sonoda, and Yoshihiro Sato \\ 青山由利*, 吉田雄三*, 園田よし子, 佐藤良博
}

Interaction of lanosterol, 3-epilanosterol, 3-oxolanosta-8,24-diene, 3-methylenelanost-8-ene and lanosterol acetate with cytochrome P-450 $14 \mathrm{DM}$ were studied. The cytochrome mediated the $14 \alpha$-demethylation of 3 -epilanosterol with nearly the same activity as lanosterol but could not mediate the $14 \alpha$-demethylation of the 3 -methylene derivative and the 3 -acetate, The cytochrome catalyzed the $14 \alpha$-demethylation of the 3-oxo derivative with low rate. Based on these and some additional observations the hydrogen bond formation between the 3-hydroxy group of lanosterol and the specific amino acid residue in the substrate site is assumed to be essential for orienting the substrate in the substrate site of the cytochrome.

* 本報告は Biochim. Biophys. Acta, 1006, 209-213 (1989) に発表.

** 武庫川女子大・薬学部 